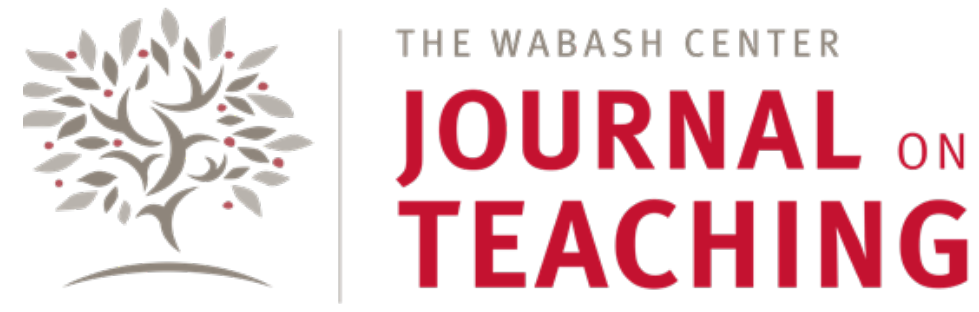

SPECIAL TOPIC

\title{
Teaching the Bible as a Threshold Concept in a Liberal Arts Context
}

\author{
Tat-siong Benny Liew \\ College of the Holy Cross
}

\begin{abstract}
This short essay describes a teaching strategy that addresses a key threshold concept in introductory biblical studies courses - that the Bible itself is a construct. It is a companion essay to John Van Maaren's, "Transformative Concepts and Troublesome Knowledge: Toward a Threshold Concept Framework for Biblical Studies," also published in this issue of the journal.
\end{abstract}

\section{KEYWORDS}

Bible intro course, threshold concepts, constructed nature of the Bible, Diego Velázquez, Titus Kaphar, US Constitution

John Van Maaren describes threshold concepts as conceptual gateways through which students need to pass if they are to make further meaningful progress and optimize their subsequent learning within that discipline (2020). Threshold concepts are transformative, integrative, irreversible, and troublesome. A threshold concept in my undergraduate biblical studies classroom is that of the Bible itself as a construct.

Is the Bible a magic eight ball that addresses or advises a reader's personal and immediate concerns (such as which school to attend or whom to date), a timeless blueprint or set of rules that dictates how we should live, a documentary of history that provides factual information, a constitution for the church, or something else altogether? Students need to think about this, because how they read the Bible is tied to what they think the Bible is and is not.

I want students to learn that the Bible is a library of ancient books from different time periods, by various human authors, with multiple or even contradictory perspectives; that "the Bible" or the canon as they know it did not exist for early Christians for almost three centuries; that there is an evolution, elasticity, or even instability about this library because of the manuscript transmission and translation process; and that the Bible is complicit in erasing or dismissing the presence or contributions of some people. I want them to decenter the Bible as an absolute authority, but still value it as a resource with which they can think and reconsider (as we see various biblical writers did within this library of writings we call "the Bible").

I employ different strategies to help students understand the nature of the Bible, but let me share what I did in the last class session of my introductory course in the spring of 2019. I showed students Diego Velázquez's Kitchen Maid with the Last Supper at Emmaus (1618) and, without giving them the painter's or the painting's name, asked them if the painting reminded them of a biblical passage we had looked at before in class. Whether they could mention Luke 24:13-35 or not, I asked them to compare the "Road to Emmaus" passage with the painting, to bring out Luke's failure to acknowledge 
that someone needed to prepare that supper for Jesus and the two disciples. Then I engaged them in a brief conversation about how the US Constitution is viewed by some as an ultimate authority - a secular or legal Bible, if you will - and showed them a one-minute video clip of two Supreme Court Justices espousing opposing views of this Constitution: Antonin Scalia insisting that we need to know and follow the original intentions of the Constitution's authors, and Ruth Bader Ginsburg arguing that the Constitution is an imperfect step in our continuous commitment to strive for a more perfect union. After listening briefly to students' opinions on which viewpoint they preferred and why, I showed students Titus Kaphar's Ted-Talk video, “Can Art Amend History?” (2017). In this twelve-minute video, Kaphar explains how his work - he paints well-known masterpieces with strategic revisions - aims not to erase the past but only to highlight or give focus to black people who had previously been ignored or minimized so we can better evaluate the impact or implications of representations, and how his attempt is comparable to making amendments to the US Constitution without expunging any parts of the Constitution. As Kaphar puts it in his talk, his art "wrestles with the struggles of our past, but speaks to the diversity and the advances of our present" (2017).

With these activities, we had a lively discussion and I felt at the end of the course that students had genuinely struggled with the Bible as a threshold concept regardless of whether they agreed with my views about the Bible. ${ }^{1}$

\section{BIBLIOGRAPHY}

Kaphar,Titus. 2017. “Can Art Amend History?” TED video, 12:53. https://www.ted.com/talks/titus_kaphar_can_art_ amend_history?utm_campaign=tedspread\&utm_medium=referral\&utm_source=tedcomshare.

Van Maaren, John. 2019. "Transformative Concepts and Troublesome Knowledge: Toward a Threshold Concept Framework for Biblical Studies." The Wabash Center Journal on Teaching 1(1): 61-78. https://doi.org/10.31046/wabashjournal.v1i1.1526.

Velázquez, Diego. 1618. Kitchen Maid with the Supper at Emmaus. 55 X 118 cm. National Gallery of Ireland. https://www. nationalgallery.ie/art-and-artists/highlights-collection/kitchen-maid-supper-emmaus-diego-velazquez\#na.

\section{ABOUT THE AUTHOR}

Tat-siong Benny Liew is the author of Politics of Parousia (1999), and What Is Asian American Biblical Hermeneutics? (2008). He also edited the Semeia volume on "The Bible in Asian America” (with Gale Yee; 2002), Postcolonial Interventions (2009), They Were All Together in One Place? (with Randall Bailey and Fernando Segovia; 2009), Reading Ideologies (2011), Psychoanalytical Mediations between Marxist and Postcolonial Readings of the Bible (with Erin Runions; 2016), Present and Future of Biblical Studies (2018), and Colonialism and the Bible: Contemporary Reflections from the Global South (with Fernando Segovia; 2018). Liew is also the Executive Editor of Brill's Biblical Interpretation and the Series Editor of T\&T Clark's Study Guides to the New Testament.

1 I am indebted to Sonja Anderson for the exercise with Velázquez, and to Laura Nasrallah for introducing me to Kaphar’s work. 